\title{
Reclassification of Roseomonas fauriae Rihs et al. 1998 as a later heterotypic synonym of Azospirillum brasilense Tarrand et al. 1979
}

\author{
Leta O. Helsel, Dannie G. Hollis, Arnold G. Steigerwalt and Paul N. Levett† \\ Meningitis and Special Pathogens Branch, Division of Bacterial and Mycotic Diseases, Centers \\ for Disease Control and Prevention, Atlanta, GA 30333, USA
}

Correspondence

Paul N. Levett

plevett@health.gov.sk.ca

\begin{abstract}
The relatedness of Roseomonas fauriae and Azospirillum brasilense was investigated using phenotypic methods and DNA-DNA hybridization. Conventional biochemical tests did not differentiate between the two taxa. DNA-DNA hybridization experiments revealed high values for relatedness between the type strains of these species and suggest that these two taxa constitute a single species. Strains previously identified as $R$. fauriae should be reclassified as $A$. brasilense, with the name Roseomonas fauriae as a later heterotypic synonym of Azospirillum brasilense.
\end{abstract}

Roseomonas is a genus of pink-pigmented, oxidative, Gramnegative coccobacilli, first described by Rihs et al. (1993, 1998). Roseomonas species are opportunistic pathogens and have been isolated from a range of human infections including septicaemia, occurring primarily in patients with underlying medical conditions (De et al., 2004; Struthers et al., 1996). Six genomospecies were defined by DNA relatedness and by phenotypic characterization, of which three were named Roseomonas gilardii, Roseomonas cervicalis and Roseomonas fauriae (Rihs et al., 1993). Five species of Roseomonas are currently recognized, including Roseomonas mucosa (Han et al., 2003) and Roseomonas lacus (Jiang et al., 2006). Recent analyses of $16 \mathrm{~S}$ rRNA gene sequences and phenotypic characteristics suggested that $R$. fauriae was closely related to Azospirillum brasilense (Cohen et al., 2004; Han et al., 2003; Weyant \& Whitney, 2005).

There are examples of organisms that have very similar or identical 16S rRNA gene sequences that are nevertheless not classified as members of the same species (Fox et al., 1992; Gee et al., 2004). Such discrepancies are resolved by DNA reassociation studies (Stackebrandt \& Goebel, 1994). In order to determine the appropriate position of $R$. fauriae, we characterized strains of $R$. fauriae and $A$. brasilense by using phenotypic methods and DNA-DNA hybridization.

The phenotypic characteristics of five strains of $R$. fauriae and three strains of $A$. brasilense were determined using conventional methods (Weyant et al., 1995). The strains studied were R. fauriae strains ATCC $49958^{\mathrm{T}}$, C5755, C5596, E5522 and F9190 and A. brasilense strains ATCC $29145^{\mathrm{T}}$, LOD-4 and RC-1. All strains produced pink, nonhaemolytic colonies on rabbit blood agar plates, grew on

tPresent address: Saskatchewan Health, Provincial Laboratory, 3211 Albert Street, Regina, Saskatchewan S4S 5W6, Canada.
MacConkey agar but not on SS agar, cetrimide agar or citrate agar, produced optimum growth at $35^{\circ} \mathrm{C}$ and were motile by means of a single polar flagellum; the results of other tests are shown in Table 1.

For preparation of DNA, all strains were cultured on 20-30 blood agar plates and incubated for $24 \mathrm{~h}$ at $35^{\circ} \mathrm{C}$. Cells were harvested and lysed and the DNA was isolated and purified according to the method of Brenner et al. (1982). DNA from strains $R$. fauriae $610^{\mathrm{T}}$ (=ATCC $49958^{\mathrm{T}}$ ) and from $A$. brasilense ATCC $29145^{\mathrm{T}}$ was labelled with $\left[{ }^{32} \mathrm{P}\right] \mathrm{dCTP}$ using a commercial nick translation kit (BRL) and tested for reassociation with unlabelled DNA from the same strain (homologous reaction), with other strains and also with the type and reference strains studied (heterologous reactions). Relative binding ratios, i.e. $100 \times$ (percentage heterologous DNA bound to hydroxyapatite/percentage homologous DNA bound to hydroxyapatite), and the percentage divergence (the percentage of unpaired bases in related DNA sequences) were calculated as described previously (Brenner et al., 1982). Divergence was calculated to the nearest $0.5 \%$, with each $1{ }^{\circ} \mathrm{C}$ decrease in the thermal stability of a heterologous DNA duplex due to approximately $1 \%$ unpaired bases within related DNA (Bonner et al., 1973). All reactions were performed in duplicate at the optimal temperature $\left(70^{\circ} \mathrm{C}\right)$.

Using the established molecular criteria for species-level relatedness (strains whose DNAs are at least $70 \%$ related under optimal conditions and whose related sequences show $\leqslant 5 \%$ divergence; Wayne et al., 1987), the strains of $R$. fauriae and $A$. brasilense formed a single species-level hybridization group.

These data show that strains identified as $R$. fauriae are correctly classified as $A$. brasilense, the name that has priority. Accordingly, we propose that Roseomonas fauriae 
Table 1. Biochemical properties of strains of $R$. fauriae and $A$. brasilense

Symbols: +, positive; -, negative; W, weakly positive; K, alkaline; NC, no clot; IR, indicator reduced.

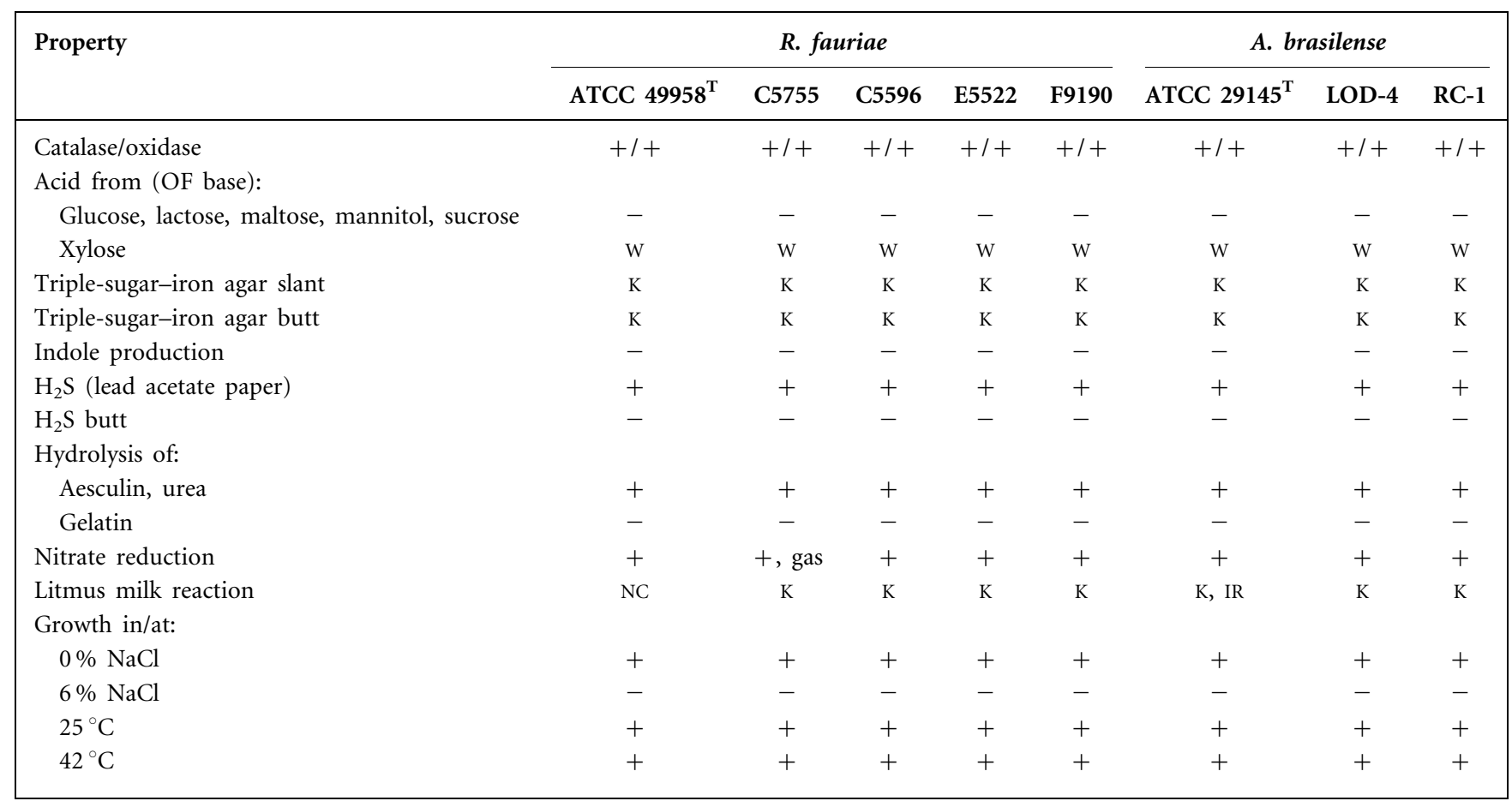

Rihs et al. 1998 be considered as a later heterotypic synonym of Azospirillum brasilense Tarrand et al. 1979.

\section{Acknowledgements}

We thank Michael Cohen and Mark Mazzola (USDA Tree Fruit Research Laboratory, Wenatchee, WA, USA) for providing isolates of A. brasilense.

\section{References}

Bonner, T. I., Brenner, D. J., Neufeld, B. R. \& Britten, R. J. (1973). Reduction in the rate of DNA reassociation by sequence divergence. J Mol Biol 81, 123-135.

Brenner, D. J., McWhorter, A. C., Knutson, J. K. \& Steigerwalt, A. G. (1982). Escherichia vulneris: a new species of Enterobacteriaceae associated with human wounds. J Clin Microbiol 15, 1133-1140.

Cohen, M. F., Han, X. Y. \& Mazzola, M. (2004). Molecular and physiological comparison of Azospirillum spp. isolated from Rhizoctonia solani mycelia, wheat rhizosphere, and human skin wounds. Can J Microbiol 50, 291-297.

De, I., Rolston, K. V. \& Han, X. Y. (2004). Clinical significance of Roseomonas species isolated from catheter and blood samples: analysis of 36 cases in patients with cancer. Clin Infect Dis 38, 1579-1584.

Fox, G. E., Wisotzkey, J. D. \& Jurtshuk, P., Jr (1992). How close is close: $16 \mathrm{~S}$ rRNA sequence identity may not be sufficient to guarantee species identity. Int J Syst Bacteriol 42, 166-170.
Gee, J. E., De, B. K., Levett, P. N., Whitney, A. M., Novak, R. T. \& Popovic, T. (2004). Use of $16 \mathrm{~S}$ rRNA gene sequencing for rapid confirmatory identification of Brucella isolates. J Clin Microbiol 42, 3649-3654.

Han, X. Y., Pham, A. S., Tarrand, J. J., Rolston, K. V., Helsel, L. O. \& Levett, P. N. (2003). Bacteriologic characterization of 36 strains of Roseomonas species and proposal of Roseomonas mucosa sp nov and Roseomonas gilardii subsp rosea subsp nov. Am J Clin Pathol 120, 256-264.

Jiang, C. Y., Dai, X., Wang, B. J., Zhou, Y. G. \& Liu, S. J. (2006). Roseomonas lacus sp. nov., isolated from freshwater lake sediment. Int J Syst Evol Microbiol 56, 25-28.

Rihs, J. D., Brenner, D. J., Weaver, R. E., Steigerwalt, A. G., Hollis, D. G. \& Yu, V. L. (1993). Roseomonas, a new genus associated with bacteremia and other human infections. J Clin Microbiol 31, 3275-3283.

Rihs, J. D., Brenner, D. J., Weaver, R. E., Steigerwalt, A. G., Hollis, D. G. \& Yu, V. L. (1998). Roseomonas gen. nov. In Validation of the Publication of New Names and New Combinations Previously Effectively Published Outside the IJSB, List no. 65. Int J Syst Bacteriol 48, 627.

Stackebrandt, E. \& Goebel, B. M. (1994). Taxonomic note: a place for DNA-DNA reassociation and 16S rRNA sequence analysis in the present species definition in bacteriology. Int J Syst Bacteriol 44, 846-849.

Struthers, M., Wong, J. \& Janda, J. M. (1996). An initial appraisal of the clinical significance of Roseomonas species associated with human infections. Clin Infect Dis 23, 729-733.

Wayne, L. G., Brenner, D. J., Colwell, R. R. \& 9 other authors (1987), International Committee on Systematic Bacteriology. Report of the ad hoc committee on reconciliation of the approaches to bacterial systematics. Int J Syst Bacteriol 37, 463-464. 
Weyant, R. S. \& Whitney, A. M. (2005). Genus XIII. Roseomonas. In Bergey's Manual of Systematic Bacteriology, 2nd edn, vol. 2, part C, pp. 88-92. Edited by D. J. Brenner, N. R. Krieg, J. T. Staley \& G. M. Garrity. New York: Springer.
Weyant, R. S., Moss, C. W., Weaver, R. E., Hollis, D. G., Jordan, J. G., Cook, E. C. \& Daneshvar, M. I. (1995). Identification of Unusual Pathogenic Gram-negative Aerobic and Facultative Anaerobic Bacteria, 2nd edn. Baltimore: Williams \& Wilkins. 